\title{
The Effect of Industrial Work Practices and Learning Outcomes Toward Students' Interest in Entrepreneurship at High School
}

\author{
Mashudi \\ Department of Economy Education, Faculty of Education and Teaching \\ Tanjungpura University \\ Pontianak, Indonesia \\ Vhrozt2@gmail.com
}

\begin{abstract}
A common problem in this study is the effect of industrial work practices of entrepreneurship and entrepreneurial learning outcomes toward students' interest in entrepreneurship in the grade XII at the state vocational high school1. Variables in this study are industrial work practices of entrepreneurship $\left(X_{1}\right)$, entrepreneurial learning outcomes $\left(X_{2}\right)$, and interest in entrepreneurship in grade XII state vocational high school (Y). The author use questionnaire and data analysis tools with using SPSS (Statistical Package For Social Science). The result of this study is that the application of industrial work practices of entrepreneurship affects to the students' interest in entrepreneurship by $15.8 \%$. The result of the statistical test on the value of the students' work practices industry showed $t_{\text {count }}>$ $t_{\text {table }}(3.543>1.994)$ and a significant value of 0.001 or less than 0.005. Entrepreneurial learning outcomes affect to the students' interest in entrepreneurship. This is based on the results of statistical tests obtained $t<t_{\text {table }}(-1929<1.994)$ and a significant value of 0.058 or more than 0.050 .
\end{abstract}

Keywords - Industry Employment Practices, Learning Outcomes Entrepreneurship, Entrepreneurship Interests

\section{INTRODUCTION}

The learning process is an activity organized, planned and implemented by educators or teachers as a vehicle to knowledge channel. Teachers should pay attention on the implementation of the learning process to individual differences in individual or students, namely on the biological aspect, intellectual, and psychological. The frame of mind thus intended that the teacher is in the approach to students and make the right situation and provide optimal impact for students to learn well in accordance with their interests.

According to [1], the meaning of entrepreneurs are people who have the courage to take risks to open a business in various opportunities. Meanwhile, according to [2] the limitation of entrepreneurial concepts leads to the nature or character of the individual, who has the bold character of assuming the risk of failure, willfully to realize innovative ideas into the real world of business and to be able to develop and even able to realize it in all aspects of work.

Entrepreneurship is very important, and this is in line with the vision of State Vocational High School 1 Monterado Bengkayang that produces human resources faithful, knowledgeable, creative, competitive, powerful and cultured.
The mission of State Vocational High School1 Monterado Bengkayang is improving the score of pure national exam annually. According to [3], the environment in the form of role models influence entrepreneurship interest. This model's roles usually look to parents, relatives, other families (grandparents, uncles, aunts, children), friends, spouses, or successful entrepreneurs who became their idols". Effective implementation of learning and guidance in a planned and organized so that each system to develop optimally, that make the students excel in various competitions, cultivate morale school community a disciplined, orderly, neat, clean, friendly, and exchanged greetings, optimize infrastructure and infrastructure and school facilities in order to improve the quality of schools and to create.

Allegedly students of the State Vocational High School 1 Monterado Bengkayang had no interest in entrepreneurship, although the practice of industrial employment and entrepreneurial knowledge has been given. Perceptions of students about entrepreneurship is an important role in cultivating students' interest in entrepreneurship. Based on interviews during the preliminary research with some students obtained the information that most of the students do not have interest in entrepreneurship.

The problems in this study were divided into two general issues and special problems. A common problem of this study is the effect of industrial work practices of entrepreneurship and entrepreneurial learning outcomes toward students' interest in entrepreneurship in the grade XII at the State Vocational High School in Monterado Bengkayang.

\section{METHODS}

\section{A. Place and Time}

This study was conducted at the State Vocational High School 1 Monterado Bengkayang on Business and Management courses. Implementation of the study began in December 2016 until completed. This study used a quantitative approach. Embodiment and symptoms observed in this study realized in the form of numbers. The results were processed using statistical analysis with SPSS.

Variables have been rated the allegedly dominant influence on interest in entrepreneurship in class XII on students of the vocational high school. The variables consist of two 
independent variables and one dependent variable. Two independent variables were the industrial working practices of entrepreneurship $\left(\mathrm{X}_{1}\right)$ and entrepreneurial learning outcomes $\left(\mathrm{X}_{2}\right)$ while the dependent variable was interested in entrepreneurship (Y).

The population was the students of grade XII in business and management study programs at the State Vocational High School1 Monterado Bengkayang. There were four classes of Grade XII and determined through random from each class, then the determined sample numbered 80 students. The validity of the data in this study was measured using SPSS program on condition the item was considered valid if the value of $r<0.05$.

According to the table Output reliability test, it can be seen that the data was valid with case a number of 80 and a percentage of $100 \%$, and no data was released (excluded).

\section{RESULTS AND DISCUSSION}

\section{A. Data Processing 1}

The data was calculated using SPSS for windows with a simple regression techniques. The data processing in question is as follows:

This output Model Summary used simple regression to describe the results of correlation between the variable $X_{1}$ to variable $Y$. The output value $R$ is 0.793 , which means the level of relationship or influence between industrial work practices value with an interest in entrepreneurship at the high category for approaching 1 Value $R$ Square $\left(R_{2}\right)$ indicates the coefficient of determination. This number will be changed in terms of percent, meaning that the percentage contribution of $\mathrm{X}_{1}$ variable influence to variable output $\mathrm{Y}$. Based on the above, the known value of $\mathrm{R}$ squared is 0.562 or $56.2 \%$. This means that contribution influence between industrial work practices value to the learning outcomes of students amounted to only $0.562 \%$ and $0.438 \%$ were contributed by other factors not included in this model.

\section{B. Data Processing 2}

Simple regression analysis used to find the effect of entrepreneurship learning value $\left(\mathrm{X}_{2}\right)$ on student entrepreneur interest (Y). Questionnaire processed is a validated and reliable questionnaire. The data will be calculated using the SPSS for windows version 17 program with a simple regression technique. The results of statistical data are as follows: Based on the results of the output value of $\mathrm{R}$ is 0.785 which means the level of influence between the value of learning outcomes with entrepreneur interest in the strong category because it is close to 1 , the significance value is 0.048. This means that there is an influence between the value of students' entrepreneurship learning outcomes with entrepreneurial interests because of the value of significance > 0.05 .

\section{Data Processing 3}

Regression analysis used to find the value of Industrial Work Practice $\left(\mathrm{X}_{1}\right)$ and Value of Entrepreneurship Learning
Outcomes $\left(\mathrm{X}_{2}\right)$ toward Interest of student entrepreneurship (Y). Process and calculation used a program SPSS version 17. For calculation, then made data processing as follows: multiple regression equation obtained from the analysis is $\mathrm{Y}=-39.935+0.871 \mathrm{X}_{1}+1.032 \mathrm{X}_{2}$. Constant $=-39.935$, this means that if industrial work practices value and learning outcomes are 0 , then entrepreneur interest is $0.871 \%$. The coefficient $\quad \mathrm{X}_{2}=1.032$ means that if other independent variables are fixed, the learning result will experience $1 \%$ increase and cause an increase in student entrepreneurship interest of $1.012 \%$.

\section{CONCLUSIONS AND SUGGESTIONS}

\section{A. Conclusions}

Based on the results of research that includes observation, test, and paired sample t-test, we can conclude some of the following:

- That the application industrial work practices influence the students' interest in entrepreneurship by $15.8 \%$. It is based on a statistical test of the value of working practices industry the tcount $>$ table (3.543> 1.994) and a significant value of 0.001 or less than 0.005 .

- That the entrepreneurial learning outcomes influence the students' interest in entrepreneurship. This is based on the results of statistical tests showed that the value of $\mathrm{t}<$ ttable $(-1929<1.994)$ and a significant value of 0.058 or more than 0.050 .

- The working practices of the industry and entrepreneurial learning outcomes influenced the students' interest in entrepreneurship. This is based on test results that the statistical significance value obtained 0.008 or less than 0.005 , which means there is an influence between the working practices of industrial and entrepreneurial learning outcomes with students' interest in entrepreneurship by $9.6 \%$.

\section{B. Suggestion}

- The application of monitoring industrial working should practice regularly scheduled and tailored teaching materials, conditions of the students and the availability of supporting infrastructure.

- The application of entrepreneurial learning should be carried out in more optimal and sustainable so as to enhance students' knowledge.

- Teachers should always give motivation to students on an ongoing basis as a reinforcement of internal motivation of students to further practice the entrepreneurial interest earned from the influence of industry work practices and learning outcomes.

\section{REFERENCES}

[1] Kasmir, Kewirausahaan, Jakarta: PT. Raja Grapindo Persada, 2011, pp 19.

[2] Bambang Hari Purnomo, Membangun Semangat Kewirausahaan, Surabaya: Alisahbana, 2005, pp19. 
[3] H. Buchari Alma, Kewiraswastaan, Bandung: Alfabeta, 2011, pp 17. 